\begin{tabular}{|c|c|c|}
\hline \begin{tabular}{|c|} 
\\
EXCELLENT \\
PUBLISHERS
\end{tabular} & $\begin{array}{c}\text { International Journal of Current Research in } \\
\text { Biosciences and Plant Biology } \\
\text { ISSN: 2349-8080 (Online) } \bullet \text { Volume } 3 \cdot \text { Number } 8 \text { (August-2016) }\end{array}$ & 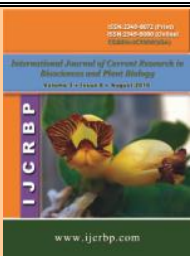 \\
\hline
\end{tabular}

\title{
Effects of Organic and Inorganic Fertilizers on the Growth and Yield of Selected Varieties of Sugarcane (Saccharum officinarum)
}

\author{
O. P. Aiyelari* \\ Department of Crop, Soil and Pest Management, The Federal University of Technology, Akure, PMB 704, Akure, \\ Ondo State, Nigeria \\ *Corresponding author.
}

\begin{abstract}
A b st ract
A field experiment was conducted at the Teaching and Research Farm (Crop section) of the Federal University of Technology Akure, Ondo State, Nigeria to examine the effects of organic, inorganic and organomineral fertilizer on the growth and yield of sugarcane (Saccharum officinarum L). The experiment was a 3 x 6 factorial scheme laid out in a randomized complete block design (RCBD) with three replications per treatment. Three varieties of sugar cane (F141, Ibon007 and Hausani), five fertilizer sources $(250 \mathrm{~kg} / \mathrm{ha}$ organomineral fertilizer, 5 tons/ha organic fertilizer, 5 tons/ha poultry manure, $200 \mathrm{~kg} / \mathrm{ha}$ organomineral fertilizer, and 200kg/ha NPK20:10:10) and control (no fertilizer/manure application) were used. The growth parameters assessed include: plant height $(\mathrm{cm})$, stem girth $(\mathrm{cm})$, number of leaves, and number of tillers; cane yield $(\mathrm{kg} / \mathrm{ha})$ and proximate and chemical composition of the cane was determined. Results from the study showed that the varieties differed in most of the growth and yield attributes measured. The improved sugarcane varieties (F141 and Ibon 007) produced significantly higher numbers of leaves and tillers compared to the local (Hausani) variety. The Hausani variety gave higher (but not significant $(p=0.05)$ cane yield compared with the improved varieties. Application of $250 \mathrm{~kg} / \mathrm{ha}$ sunshine organomineral fertilizer also resulted in significantly $(p=0.05)$ higher cane yields. The analysis of the proximate composition of the sugarcane varieties showed that the percentage ash, crude protein, carbohydrates, crude fibre, fats and moisture contents differed significantly across treatments. The highest percentages of crude protein and fibre were recorded in plots treated with $5 \mathrm{t} / \mathrm{ha}$ poultry manure. Plots treated with 5 tons/ha organic fertilizer recorded the highest percentage of fat, while $200 \mathrm{~kg} / \mathrm{ha}$ organomineral fertilizer produced highest carbohydrate contents. Application of $250 \mathrm{~kg} / \mathrm{ha}$ of organomineral fertilizer produced overall highest growth and yield compared with other treatments. This result suggests that the use of organomineral and organic fertilizers should be encouraged in sugarcane production to obtain increase in the productivity of sugarcane.
\end{abstract}

\section{Introduction}

Sugarcane (Saccharum officinarum L.) is one of the most important commercial crops grown by farmers in countries of the tropics (Sivanesan and Waller, 1986; Alvaris, 2008) and it improves the socio-economic

\section{Article Info}

Accepted: 15 June 2016

Available Online: 06 August 2016

\section{Ke ywords}

Growth and yield Organomineral fertilizer Saccharum officinarum Sugarcane conditions in various aspects. The crop is used for the production of sugar, molasses for livestock feeds, alcohol, bagasses used for cooking fuel, and trash used for mulching and as organic fertilizer (Gana, 2008). In Brazil, sugarcane is readily available as forage for dairy cattle. Sugarcane is used as strategic forage particularly 
in the dry season to prevent overgrazing of the pasture and for wine making (Hussain et al., 2007). Chewing sugarcane can locally be processed into mazarkwaila and alewa for drinking akamu and gari (Busari et al., 1995). Sugarcane is one of the most important crops in the world because of its strategic position and immense uses in the daily life of any nation as well as for industrial uses aimed at nutritional and economic sustenance. It is an essential food commodity with great potentials for foreign exchange earnings. The main product which is sugar is used universally as sweeteners, blender and as preservatives. It has also become an essential part in many diets, and almost indispensable in the food manufacturing and pharmaceutical industries (NSDC, 2003; Girei and Giroh, 2012).

Sugarcane contributes about $60 \%$ of the total world sugar requirement while the remaining $40 \%$ comes from sugar beet (Onwueme and Sinha, 1999). Sugar as a bi product of sugarcane is still the most widely used as caloric food in all countries especially among those of lower income. It is a tropical crop that usually takes between $8-12$ months to reach its maturity. Matured cane may be green, yellow, purplish or reddish. The cane is considered ripe when sugar content is at its maximum (Onwueme and Sinha, 1993).

Sugarcane is an economically important crop. It provides a rich source of sucrose, alcohol and organic matter waste which is utilized as fertilizer. Sugarcane was cultivated vegetatively as noble canes until the end of 20th century. Today sugarcane is known as an aneuploid hybrid crop derived from a cross between Saccharum officinarum L. and a wild relative Saccharum spontaneum, through the process of nobilization (Mumtaz et al., 2011).

The total world area and production of sugarcane as estimated in 1989 were 16.7 million hectares and 1,007 million metric tons, respectively. Brazil, china, Cuba, Mexico, Pakistan, Thailand, the USA, Colombia, Australia and Indonesia produced over half of the total world sugarcane production while Africa had 1.2 million hectares with 72.1 million metric tons, respectively (Onwueme and Sinha, 1993). The important sugarproducing countries in the tropical Africa are Mauritius, Kenya, Sudan, Zimbabwe, Madagascar, Ivory Coast, Ethiopia, Malawi, Zambia, Tanzania, Nigeria, Cameroon and Zaire. Nigeria is one of the most important producers of the crop with a land potential of over 500,000 hectares of suitable cane field capable of producing over 3.0 million metric tons of sugarcane. If processed, it will yield about 3.0 million metric tons of sugar (NSDC, 2003). Nigeria is noted to be abundantly blessed with human, water and environmental potentials for the production of sugarcane. Areas with high potentials for commercial sugarcane and sugar production have been identified through studies sponsored by the Federal Ministry of Industry and conducted by Dutch consultants HVA in the early eighties. It should be pointed out that in most of the areas in the Northern States where water for irrigation is available; sugarcane cultivation in large quantities is feasible. The crop can be rotated or even inter-planted with other crops where land with adequate sources of water abounds like in the various River Basin Development Authority Areas.

Generally, sugarcane for domestic consumption is produced more than that produced for industrial use. Thus, chewing cane account for between $55-65$ percent of the total cane production. The bulk of these chewing sugarcane is consumed raw for its sweetness of the juice but some of it also is processed into variety of products such as sugar, molasses, baggasse Jaggery (Mazarkwaila), sweets (Alewa) and left over leaves/stalks (Misari, 1997).

Use of inorganic fertilizers can improve crop yields and $\mathrm{pH}$, total nutrient content and nutrient availability, but its use is limited due to scarcity, high cost nutrient imbalance and soil acidity.

Due to continuous application of only inorganic fertilizers and plant protection chemicals in agriculture, the soils have been badly degraded. It has destroyed stable traditional ecosystem of the soil (Palaniappan and Annadurai, 1999). There is need to encourage more productive, cost efficient and eco-friendly farming system (Bhattacharya and Gehlot, 2003). The use of organic manure is based on the need for improving the sustainable productivity of soil (Singh et al., 2003). With the increased emphasis on the impact on environmental quality due to continuous use of chemical fertilizers, the integrated nutrient management system or conjunctive use of different nutrient sources is an alternative and is characterized by reduced input of chemical fertilizers and combined use of chemical fertilizers with organic materials such as animal manures, crop residues, green manure, compost and organomineral fertilizers. Also, little researches have been conducted on the effects of organomineral fertilizers on sugarcane in previous years. From the foregoing, this study was conducted to examine the effects of different forms of fertilizers (NPK 20:10:10, organic fertilizer, organomineral fertilizer and 
poultry manure) on the growth and yield of sugarcane; the study also aims at determining the proximate contents of the cane in terms of moisture, fibre, ash, fat and protein and also the nutrients present.

\section{Materials and methods}

Field experiment was conducted at the Teaching and Research Farm of the Federal University of Technology Akure, Ondo State Nigeria between July, 2013 and July, 2014 to determine the effects of organic, inorganic and organomineral fertilizer on the growth and yield of sugarcane (Saccharum officinarum L.). The area lies within the tropical rainforest belt, latitude $5^{0} \mathrm{~N}$ and longitude $15^{0} \mathrm{E}$. The rainfall pattern of Akure is bimodal with a wet season of about eight months occurring from April to October and with a brief dry spell, which in most cases occurs in the second half of August. The peak rainfall periods are June, July, September and October while the short dry season is from November, December through February and March. The mean daily temperature in Akure ranges from about $25^{\circ} \mathrm{C}$ and $37^{\circ} \mathrm{C}$. The site has been cultivated in previous years continuously for maize, vegetables and water melon. The experimental field was manually cleared and divided into plots. The experiment was a $3 \times 6$ factorial scheme arranged in a randomized complete block design (RCBD) with three replicates. Each replicate consists of eighteen treatments which are; (i) Ibon $007+250 \mathrm{~kg} / \mathrm{ha}$ organomineral fertilizer; (ii) $\mathrm{F} 141+250 \mathrm{~kg} / \mathrm{ha}$ organomineral fertilizer; (iii) Hausani + $250 \mathrm{~kg} / \mathrm{ha}$ organomineral fertilizer; (iv) Ibon $007+5$ tonnes/ha organic fertilizer; (v) F141 + 5 tons/ha organic fertilizer; (vi) Hausani +5 tonnes/ha organic fertilizer; (vii) Ibon $007+200 \mathrm{~kg} / \mathrm{ha}$ NPK; (viii) F141 + $200 \mathrm{~kg} / \mathrm{ha}$ NPK; (ix) Hausani + 200 kg/ha NPK; (x) Ibon $007+$ 5tons/ha poultry manure; (xi) F141 + 5tonnes/ha poultry manure; (xii) Hausani +5 tonnes/ha poultry manure; (xiii) Ibon $007+200 \mathrm{~kg} / \mathrm{ha}$ organomineral fertilizer; (xiv) F141 $+200 \mathrm{~kg} / \mathrm{ha}$ organomineral fertilizer; (xv) Hausani +200 $\mathrm{kg} / \mathrm{ha}$ organomineral fertilizer; (xvi) Ibon 007 only; (xvii) F141 only; and (xviii) Hausani only. Total land area measured $21 \mathrm{~m} \times 13 \mathrm{~m}$. Plot sizes measures $2 \mathrm{~m} \times 1 \mathrm{~m}$ with $1 \mathrm{~m}$ alley ways between plots and $1.5 \mathrm{~m}$ between the replicates. There were nine (9) sugarcane plants per plot. Two sugarcane varieties (Ibon 007; T141;) were sourced from the National Cereals Research Institute, Badegi Niger State, while the third variety (Hausani) was obtained locally at the Shasha market in Akure, Ondo State. The application of the various fertilizer treatments was done at exactly two months after planting; after which the various growth and yield parameters were taken. The growth parameters evaluated include height (cm) of 5 randomly selected plants measured in centimetres from the surface of the soil to the tip of the flag leaf; stem girth $(\mathrm{cm})$ measured in centimetres by Vernier calliper from bottom, mid and top portion; number of leaves, and number of tillers was done by visual counting; while the yield parameters evaluated include total yield of the matured cane $(\mathrm{kg})$ on spring balance. The percentage fat ( $\%$ fat) was determined using Soxhlet extraction method and calculated as follows:

$$
\% \mathrm{FAT}=\frac{W_{2}-W_{3}}{W_{2}-W_{1}} \times 100
$$

From the dried sample, $2 \mathrm{~g}$ was weighed and digested for nitrogen determination using Kjeldahl method. The nitrogen determined was then multiplied by a constant (6.25) to determine the protein content. For ash determination, crucibles were dried over the hot plate and cooled in the desiccator for about one hour. The crucibles were weighed $\left(\mathrm{W}_{1}\right)$. Thereafter, 1 gram of each sample was weighed inside the crucibles and weighed $\left(\mathrm{W}_{2}\right)$. The samples were pre ashed with Bunsen burner flames until sample becomes charred. The crucible was then transferred to the muffled furnace set at $550^{\circ} \mathrm{c}$. Ashing continued until a light grey or white ash was obtained. The crucibles were then cooled in the desiccator and weighed $\left(\mathrm{W}_{3}\right)$.

$$
\% \text { Ash }=\frac{W_{3}-W_{1}}{W_{2}-W_{1}} X 100
$$

All data collected were subjected to analysis of variance (ANOVA) to test treatment effects for significance using Minitab Version 17.1.0 statistical package. Significant means were separated using Tukey test at 5\% level of probability.

\section{Results}

The soil physico-chemical properties (Table 1) were analysed and the results showed that the soil of the experimental site was fairly acidic and contained various nutrients (Nitrogen, Phosphorus, Calcium and Magnesium) at moderate proportions. The soil of the experimental area was sandy loam containing sand $(525.16 \mathrm{~g} / \mathrm{kg})$, silt $(172.54 \mathrm{~g} / \mathrm{kg})$ and clay $(302.30 \mathrm{~g} / \mathrm{kg})$. Table 2 shows the effects of sunshine organic manure, poultry manure, NPK (20-10-10), and organomineral fertilizers on the height of sugarcane. Plant height differed significantly $(p<0.05)$ across treatments throughout the experiment except at the $7^{\text {th }}$ month after planting. At the $9^{\text {th }}$ month after planting, plots treated 
with $200 \mathrm{~kg} / \mathrm{ha}$ organomineral fertilizer recorded the highest plant height $(229.35 \mathrm{~cm})$ while the least plant height $(194.78 \mathrm{~cm})$ was recorded in the control plots.

Table 1. Pre-cropping soil analysis

\begin{tabular}{ll}
\hline Routine analysis & Value \\
\hline $\mathrm{pH} 1: 1 \mathrm{H}_{2} \mathrm{O}$ & 6.15 \\
Nitrogen $\left(\mathrm{g} \mathrm{kg}^{-1}\right)$ & 9.8 \\
Organic carbon $\left(\mathrm{g} \mathrm{kg}^{-1}\right)$ & 17.8 \\
Phosphorus $\left(\mathrm{mg} \mathrm{kg}^{-1}\right)$ & 8.8 \\
Exchangeable cations $(\mathbf{c m o l} / \mathbf{k g})$ & \\
Potassium & 0.54 \\
Calcium & 0.85 \\
Magnessium & 1.76 \\
Particle size $(\mathrm{g} / \mathrm{kg})$ & \\
Sand & 525.16 \\
Silt & 172.54 \\
Clay & 302.3 \\
\hline
\end{tabular}

Table 2 also shows the effects of the fertilizer types on the stem girth of sugarcane. Stem girth differed significantly $(p<0.05)$ across treatments. Plots treated with fertilizers/manure consistently recorded higher stem girth over the control. At nine months after planting (9 MAP), plots treated with $200 \mathrm{~kg} / \mathrm{ha}$ NPK fertilizer recorded the highest stem girth $(4.40 \mathrm{~cm})$ while the lowest stem girth $(3.68 \mathrm{~cm})$ was recorded in the control plots. The effects of the fertilizer types on number of tillers of sugarcane are presented in Table 2. Number of tillers differed significantly $(p<0.05)$ across treatments and also throughout the experiment. The highest number of tillers (13.78) was recorded in plots treated with $250 \mathrm{~kg} / \mathrm{ha}$ organomineral fertilizers at 9 months after planting while the lowest number of tillers (8.00) was recorded in the control plots. Table 3 shows the effects of sunshine organic manure, poultry manure, NPK (20-10$10)$, and organomineral fertilizers on the height of sugarcane varieties. Plant height differed significantly ( $p$ $<0.05)$ across the varieties throughout the experiment. The improved varieties (F141 and Ibon 007) consistently recorded the highest plant height. At nine months after planting (9MAP) plant height ranged from $193.45 \mathrm{~cm}$ in the Hausani variety to $236.15 \mathrm{~cm}$ in Ibon 007. Table 3 also shows the effects of sunshine organic manure, poultry manure, NPK (20-10-10), and organomineral fertilizers on stem girth of the sugarcane varieties. Stem girth differed significantly $(p<0.05)$ across all the varieties throughout the experiment. The Hausani varieties consistently recorded the highest stem girth. Stem girth ranged from $3.9 \mathrm{~cm}$ in F141 to $4.20 \mathrm{~cm}$ in Ibon007 to $4.32 \mathrm{~cm}$ in Hausani variety. The effects of sunshine organic manure, poultry manure, NPK (20-1010 ), and organomineral fertilizers on number of tillers of the sugarcane varieties are also presented in Table 3 . The number of tillers differed significantly $(p<0.05)$ across varieties used for the experiment. At 9 months after planting, the highest number of tillers (11.56) was recorded in the F141 variety while the lowest number of tillers (9.67) was recorded in the Hausani variety.

Table 2. Effects of fertilizer types on height $(\mathrm{cm})$, stem girth and number of tillers of sugarcane.

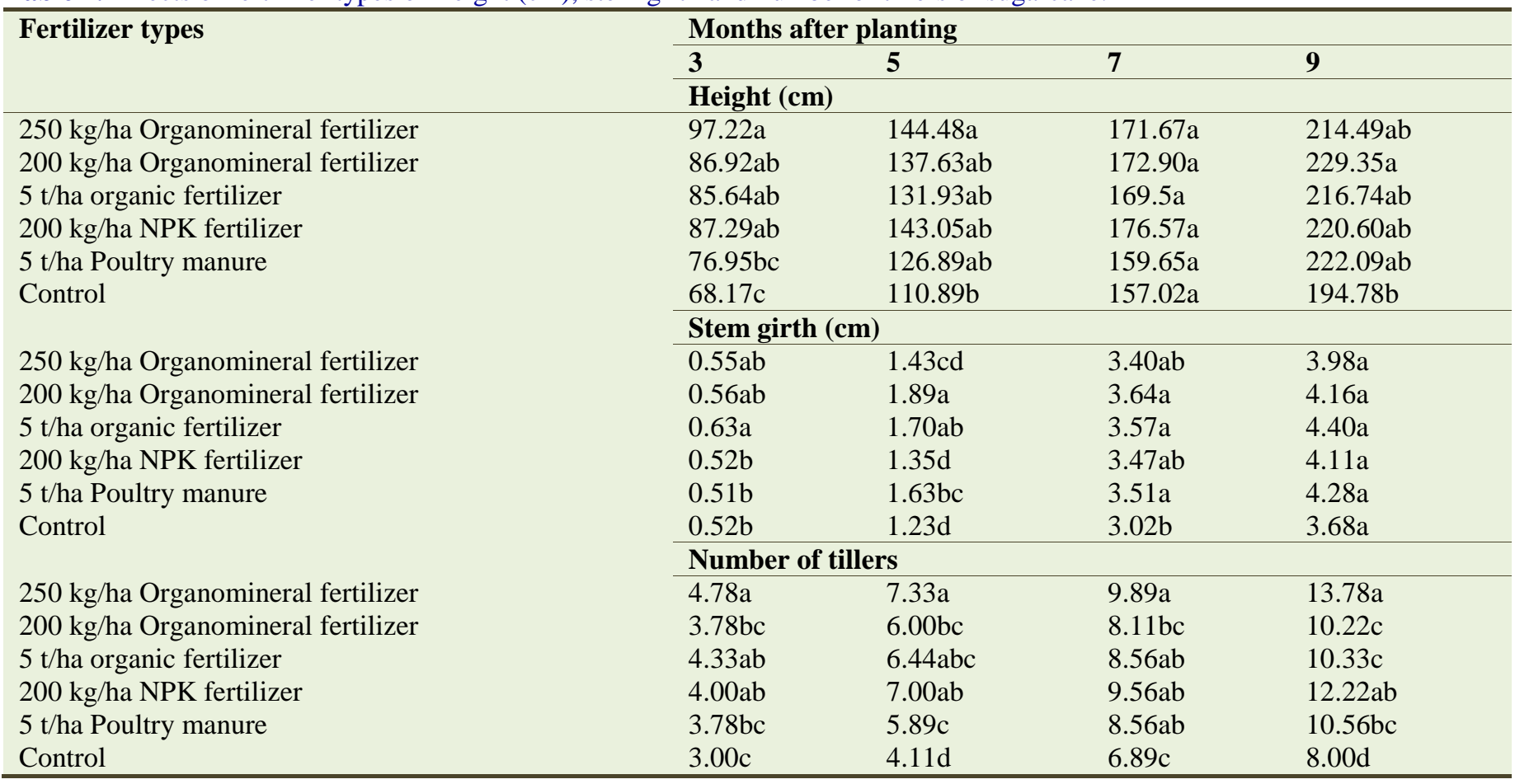


Table 3. Effects of fertilizer types on height $(\mathrm{cm})$, stem girth and number of tillers of sugarcane varieties.

\begin{tabular}{|c|c|c|c|c|}
\hline \multirow{3}{*}{ Variety } & \multicolumn{4}{|c|}{ Months after planting } \\
\hline & 3 & 5 & 7 & 9 \\
\hline & \multicolumn{4}{|c|}{ Height (cm) } \\
\hline F141 & $87.04 \mathrm{~b}$ & $133.24 \mathrm{ab}$ & $172.58 \mathrm{a}$ & $219.42 \mathrm{a}$ \\
\hline Ibon 007 & $102.78 \mathrm{a}$ & $146.68 \mathrm{a}$ & $183.59 \mathrm{a}$ & $236.15 \mathrm{a}$ \\
\hline \multirow[t]{2}{*}{ Hausani } & $61.28 \mathrm{c}$ & $117.50 \mathrm{~b}$ & $147.50 \mathrm{~b}$ & $193.45 b$ \\
\hline & \multicolumn{4}{|c|}{ Stem girth $(\mathrm{cm})$} \\
\hline F141 & $0.50 \mathrm{~b}$ & $1.10 \mathrm{c}$ & $3.21 \mathrm{~b}$ & $3.90 \mathrm{~b}$ \\
\hline Ibon 007 & $0.56 \mathrm{a}$ & $1.45 \mathrm{~b}$ & $3.35 \mathrm{~b}$ & $4.20 \mathrm{ab}$ \\
\hline \multirow[t]{2}{*}{ Hausani } & $0.58 \mathrm{a}$ & $2.06 \mathrm{a}$ & $3.74 \mathrm{a}$ & $4.32 \mathrm{a}$ \\
\hline & \multicolumn{4}{|c|}{ Number of tillers } \\
\hline F141 & $4.39 a$ & $6.56 \mathrm{a}$ & $9.39 \mathrm{a}$ & $11.56 \mathrm{a}$ \\
\hline Ibon 007 & $4.17 \mathrm{a}$ & $6.61 \mathrm{a}$ & $9.28 \mathrm{a}$ & $11.32 \mathrm{a}$ \\
\hline Hausani & $3.28 \mathrm{~b}$ & $5.22 \mathrm{~b}$ & $7.11 \mathrm{~b}$ & $9.67 \mathrm{~b}$ \\
\hline
\end{tabular}

Means followed by the same letter in the same column for each parameter are not significantly different from each other at 5\% level of probability by Tukey test.

The interaction effects of sunshine organic fertilizer, N.P.K (20-10-10), poultry manure and organomineral fertilizers and varieties on the height of sugarcane are presented in Table 4. Plant height increases appreciably but did not differ significantly $(p>0.05)$ across treatments in the $5^{\text {th }}$ and $7^{\text {th }}$ month after planting. However, plant height differed significantly $(p<0.05)$ at 3 and 5 months after planting. The highest plant height were recorded at 9 months after planting (9MAP) in plots treated with $200 \mathrm{~kg} / \mathrm{ha}$ organomineral fertilizer + Ibon $007(250.89 \mathrm{~cm})$ and $5 \mathrm{ton} / \mathrm{ha}$ organic fertilizer + Ibon $007(249.20 \mathrm{~cm})$. The interaction effects of sunshine organic fertilizer, N.P.K (20-10-10), poultry manure and organomineral fertilizers and varieties on stem girth of sugarcane are shown in Table 5. Stem girth differed significantly $(p<0.05)$ across treatments and throughout the experiment. At nine months after planting (9 MAP), plots treated with $200 \mathrm{~kg} / \mathrm{ha}$ NPK fertilizer + Hausani and $250 \mathrm{~kg} / \mathrm{ha}$ organomineral fertilizer + Hausani recorded the highest stem girth while the lowest stem girth $(0.47 \mathrm{~cm})$ was recorded in the control + Hausani. At 5 months after planting, plots treated with $200 \mathrm{~kg} / \mathrm{ha}$ organomineral fertilizer + Hausani recorded the highest stem girth with $2.38 \mathrm{~cm}$. At 7 months after planting, plots treated with 5tons/ha Poultry manure + Hausani recorded the highest stem girth with $4.09 \mathrm{~cm}$. However, at 9 months after planting, stem girth increases appreciably but did not differ significantly across treatments.

Table 4. Interactions of fertilizer types and varieties on height $(\mathrm{cm})$ of sugarcane.

\begin{tabular}{|c|c|c|c|c|c|}
\hline \multirow{2}{*}{ Fertilizer types } & \multirow{2}{*}{ Variety } & \multicolumn{4}{|c|}{ Months after planting } \\
\hline & & 3 & 5 & 7 & 9 \\
\hline $250 \mathrm{~kg} / \mathrm{ha}$ Organomineral fertilizer & F141 & $87.13 \mathrm{bcde}$ & $131.84 \mathrm{a}$ & $166.79 a$ & $209.12 \mathrm{ab}$ \\
\hline $250 \mathrm{~kg} / \mathrm{ha}$ Organomineral fertilizer & Ibon 007 & $126.72 \mathrm{a}$ & $170.74 \mathrm{a}$ & $201.22 \mathrm{a}$ & $243.27 \mathrm{ab}$ \\
\hline $200 \mathrm{~kg} / \mathrm{ha}$ Organomineral fertilizer & F141 & $92.56 \mathrm{abcde}$ & $129.82 \mathrm{a}$ & $164.25 \mathrm{a}$ & $231.42 \mathrm{ab}$ \\
\hline $200 \mathrm{~kg} / \mathrm{ha}$ Organomineral fertilizer & Ibon 007 & $110.94 \mathrm{ab}$ & $159.73 \mathrm{a}$ & $196.70 \mathrm{a}$ & $250.89 a$ \\
\hline 5 t/ha organic fertilizer & Ibon 007 & $102.16 \mathrm{abc}$ & $159.17 \mathrm{a}$ & $196.99 a$ & $249.20 \mathrm{a}$ \\
\hline $5 \mathrm{t} /$ ha organic fertilizer & Hausani & 60.96defg & $113.63 \mathrm{a}$ & $144.21 \mathrm{a}$ & $189.09 \mathrm{ab}$ \\
\hline $200 \mathrm{~kg} / \mathrm{ha}$ NPK fertilizer & F141 & $85.86 \mathrm{bcdef}$ & $130.11 \mathrm{a}$ & $187.11 \mathrm{a}$ & $220.72 \mathrm{ab}$ \\
\hline $200 \mathrm{~kg} / \mathrm{ha}$ NPK fertilizer & Ibon 007 & $97.68 \mathrm{abcd}$ & $143.25 \mathrm{a}$ & $176.66 \mathrm{a}$ & $229.78 \mathrm{ab}$ \\
\hline $200 \mathrm{~kg} / \mathrm{ha}$ NPK fertilizer & Hausani & $73.38 \mathrm{cdefg}$ & $122.42 \mathrm{a}$ & $144.77 \mathrm{a}$ & $199.72 \mathrm{ab}$ \\
\hline 5 t/ha Poultry manure & F141 & $82.12 \mathrm{bcdefg}$ & $138.24 \mathrm{a}$ & $163.43 \mathrm{a}$ & $230.82 \mathrm{ab}$ \\
\hline Control & Ibon 007 & $79.87 \mathrm{bcdefg}$ & $119.09 a$ & $167.387 \mathrm{a}$ & $202.77 \mathrm{ab}$ \\
\hline Control & Hausani & $48.85 \mathrm{~g}$ & $100.47 \mathrm{a}$ & $138.283 \mathrm{a}$ & $180.67 b$ \\
\hline
\end{tabular}

Means followed by the same letter in the same column are not significantly different from each other at $5 \%$ level of probability by Tukey test. 
Table 5. Interactions of fertilizer types and varieties on stem girth $(\mathrm{cm})$ of sugarcane.

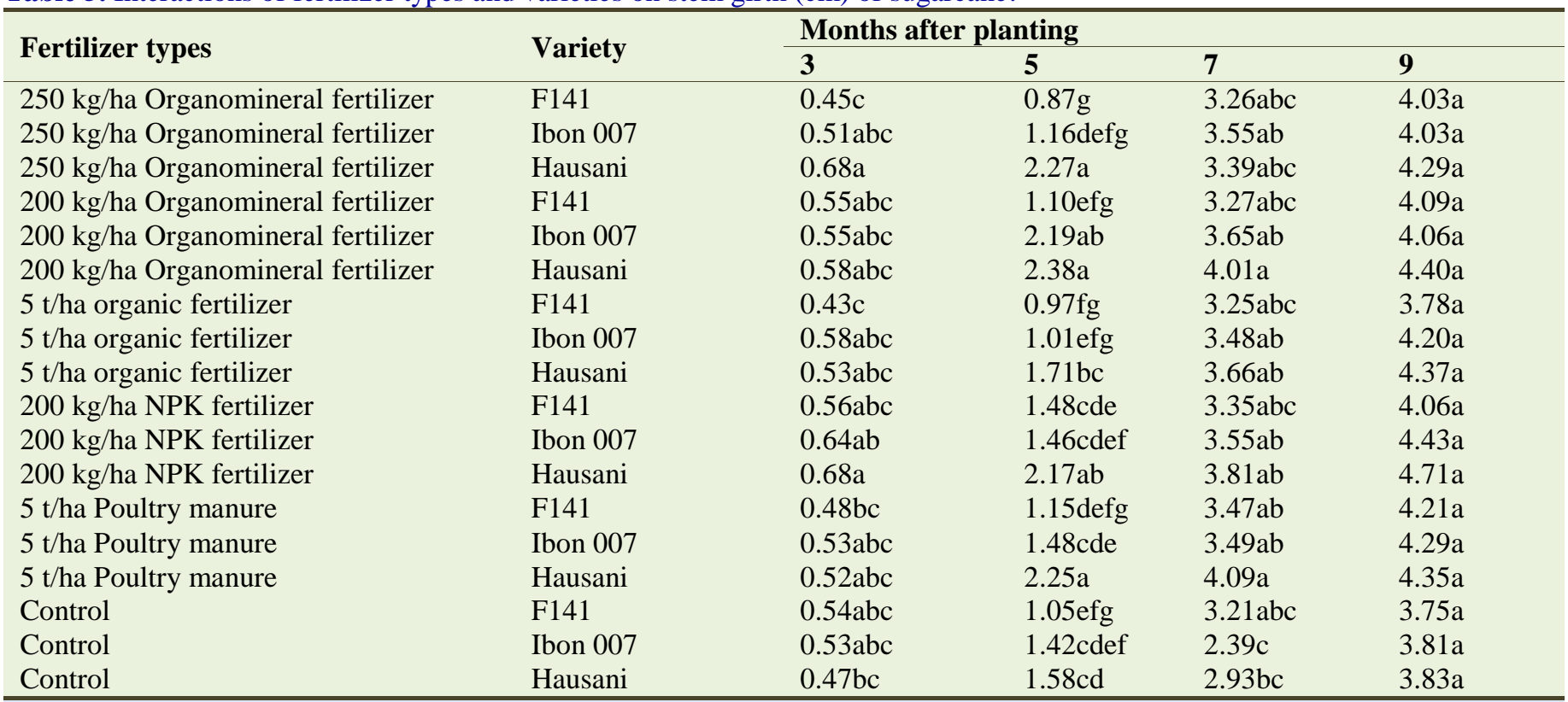

Means followed by the same letter in the same column are not significantly different from each other at $5 \%$ level of probability by Tukey test.

Table 6. Interactions of fertilizer types and varieties on number of tillers of sugarcane.

\begin{tabular}{|c|c|c|c|c|c|}
\hline Fertilizer types & Variety & \multicolumn{4}{|c|}{ Months after planting } \\
\hline $250 \mathrm{~kg} / \mathrm{ha}$ Organomineral fertilizer & Ibon 007 & $5.67 \mathrm{a}$ & $8.33 \mathrm{a}$ & $11.00 \mathrm{a}$ & $13.33 \mathrm{abc}$ \\
\hline $200 \mathrm{~kg} / \mathrm{ha}$ Organomineral fertilizer & F141 & 4.00abcd & $5.33 \mathrm{cdef}$ & 9.00abcde & $11.00 \mathrm{abcd}$ \\
\hline $200 \mathrm{~kg} / \mathrm{ha}$ Organomineral fertilizer & Ibon 007 & 4.00abcd & 7.00abcd & 8.67 abcde & $11.00 \mathrm{abcd}$ \\
\hline $200 \mathrm{~kg} / \mathrm{ha}$ Organomineral fertilizer & Hausani & $3.33 \mathrm{~cd}$ & $5.67 \mathrm{cdef}$ & $6.67 \mathrm{de}$ & $8.67 \mathrm{de}$ \\
\hline $5 \mathrm{t} /$ ha organic fertilizer & Ibon 007 & 4.33abcd & $6.67 \mathrm{abcd}$ & 8.67abcde & 10.67abcde \\
\hline $5 \mathrm{t} /$ ha organic fertilizer & Hausani & $3.33 \mathrm{~cd}$ & $4.33 \mathrm{ef}$ & $7.00 \mathrm{cde}$ & $8.67 \mathrm{de}$ \\
\hline $200 \mathrm{~kg} / \mathrm{ha}$ NPK fertilizer & F141 & 4.67abcd & $7.33 \mathrm{abc}$ & $10.00 \mathrm{abc}$ & $12.67 \mathrm{abc}$ \\
\hline $200 \mathrm{~kg} / \mathrm{ha}$ NPK fertilizer & Ibon 007 & 4.00abcd & $6.67 \mathrm{abcd}$ & $10.33 \mathrm{ab}$ & $13.67 \mathrm{ab}$ \\
\hline $200 \mathrm{~kg} / \mathrm{ha}$ NPK fertilizer & Hausani & $3.33 \mathrm{~cd}$ & 7.00abcd & 8.33abcde & $10.33 \mathrm{bcde}$ \\
\hline $5 \mathrm{t} /$ ha Poultry manure & F141 & 4.33abcd & $6.00 \mathrm{bcde}$ & 9.33abcd & 11.00abcd \\
\hline Control & Ibon 007 & $3.00 \mathrm{~d}$ & $4.33 \mathrm{ef}$ & $7.00 \mathrm{cde}$ & $8.33 \mathrm{de}$ \\
\hline Control & Hausani & $3.00 \mathrm{~d}$ & $3.67 f$ & $6.00 \mathrm{e}$ & $7.00 \mathrm{e}$ \\
\hline
\end{tabular}

Means followed by the same letter in the same column are not significantly different from each other at $5 \%$ level of probability by Tukey test.

Table 6 shows the interaction of sunshine organic manure, poultry manure, NPK (20-10-10), and organomineral fertilizers and varieties on number of tillers of sugarcane. Number of tillers differed significantly $(p<0.05)$ across varieties in the treatments and also throughout the experiment. The highest number of tillers was recorded in plots treated with $250 \mathrm{~kg} / \mathrm{ha}$ organomineral fertilizer + Ibon 007. At 9 months after planting the highest number of tillers (14.33) was recorded in plots treated with $250 \mathrm{~kg} / \mathrm{ha}$ organomineral fertilizer + F141; while the lowest number of tillers (7.00) was recorded in the control plots. Data presented in Table 7 shows the effects of the fertilizer/manure types on number of leaves of sugarcane. Number of leaves differed significantly $(p<0.05)$ across treatments. Plots treated $250 \mathrm{~kg} / \mathrm{ha}$ organomineral fertilizer 
consistently recorded the highest number of leaves throughout the experiment. Number of leaves produced by plants in the plots treated with $200 \mathrm{~kg} / \mathrm{ha}$ NPK fertilizer and those planted in plots treated with $200 \mathrm{~kg} / \mathrm{ha}$ sunshine organomineral fertilizers were similar. Number of leaves ranged from 18.89 in the control plots to 26.89 in plots treated with $250 \mathrm{~kg} / \mathrm{ha}$ organomineral fertilizer. The effects of sunshine organic manure, poultry manure, NPK (20-10-10), and organomineral fertilizers on number of leaves of the sugarcane varieties are shown in Table 8. Number of leaves differed significantly $(p=0.05)$ across the sugar cane varieties till the 5 MAP. The
Hausani variety recorded the least number of leaves throughout the experiment; while the highest was produced in Ibon007 variety. Table 9 shows the interaction effects of the fertilizer types and the sugarcane varieties on number of leaves of the sugarcane. Number of leaves differed significantly $(p<$ $0.05)$ across the sugarcane varieties under the different fertilizer types. The highest number of leaves was produced by variety 2 (Ibon007) planted on the plots treated with $250 \mathrm{~kg} / \mathrm{ha}$ organomineral fertilizer; while the least number of leaves was also recorded in the control plots with Ibon007.

Table 7. Effects of fertilizer types on number of leaves of sugarcane.

\begin{tabular}{|c|c|c|c|}
\hline \multirow{2}{*}{ Treatments } & \multicolumn{3}{|c|}{ Months after planting } \\
\hline & 3 & 5 & 7 \\
\hline $200 \mathrm{~kg} / \mathrm{ha}$ NPK fertilizer & $12.22 \mathrm{a}$ & $17.89 \mathrm{ab}$ & $24.11 b$ \\
\hline 5 t/ha Poultry manure & $9.56 \mathrm{~b}$ & $16.00 \mathrm{~d}$ & $21.89 \mathrm{c}$ \\
\hline Control (No fertilizer application at all) & $7.56 \mathrm{c}$ & $12.11 \mathrm{e}$ & $18.89 \mathrm{~d}$ \\
\hline
\end{tabular}

Table 8. Effects of organic, inorganic and organomineral fertilizers on number of leaves of sugarcane varieties.

\begin{tabular}{|c|c|c|c|}
\hline \multirow{2}{*}{ Variety } & \multicolumn{3}{|c|}{ Months after planting } \\
\hline & 3 & 5 & 7 \\
\hline F141 & $10.44 a$ & $16.44 a$ & $22.67 \mathrm{a}$ \\
\hline Ibon 007 & $9.78 b$ & $16.61 \mathrm{a}$ & $23.00 \mathrm{a}$ \\
\hline
\end{tabular}

Means followed by the same letter in the same column are not significantly different from each other at $5 \%$ level of probability by Tukey test.

Table 9. Interactions of fertilizer types and varieties on number of leaves of sugarcane.

\begin{tabular}{|c|c|c|c|c|}
\hline \multirow{2}{*}{ Fertilizer types } & \multirow{2}{*}{ Variety } & \multicolumn{3}{|c|}{ Months after planting } \\
\hline & & 3 & 5 & 7 \\
\hline $250 \mathrm{~kg} / \mathrm{ha}$ Organomineral fertilizer & F141 & $11.00 \mathrm{bcd}$ & $18.33 \mathrm{abc}$ & 23.00bcde \\
\hline $250 \mathrm{~kg} / \mathrm{ha}$ Organomineral fertilizer & Ibon 007 & $10.00 \mathrm{cde}$ & $19.33 \mathrm{a}$ & $28.33 \mathrm{a}$ \\
\hline $250 \mathrm{~kg} / \mathrm{ha}$ Organomineral fertilizer & Hausani & $10.00 \mathrm{cde}$ & $16.33 \mathrm{def}$ & $26.33 \mathrm{ab}$ \\
\hline $5 \mathrm{t} / \mathrm{ha}$ organic fertilizer & F141 & $10.33 \mathrm{bcde}$ & $16.67 \mathrm{cdef}$ & $22.67 \mathrm{cde}$ \\
\hline $5 \mathrm{t} /$ ha organic fertilizer & Ibon 007 & $11.00 \mathrm{bcd}$ & $16.67 \mathrm{cdef}$ & $22.33 \mathrm{cde}$ \\
\hline $5 \mathrm{t} /$ ha organic fertilizer & Hausani & $9.67 \mathrm{de}$ & $15.67 \mathrm{ef}$ & $20.33 \mathrm{def}$ \\
\hline $200 \mathrm{~kg} / \mathrm{ha}$ NPK fertilizer & F141 & $13.00 \mathrm{a}$ & 17.33bcde & $24.67 \mathrm{bc}$ \\
\hline $200 \mathrm{~kg} / \mathrm{ha}$ NPK fertilizer & Ibon 007 & $11.67 \mathrm{abc}$ & $19.00 \mathrm{ab}$ & $23.67 \mathrm{bcd}$ \\
\hline $200 \mathrm{~kg} / \mathrm{ha}$ NPK fertilizer & Hausani & $12.00 \mathrm{ab}$ & 17.33bcde & $24.00 \mathrm{bc}$ \\
\hline 5 t/ha Poultry manure & F141 & $10.00 \mathrm{cde}$ & $16.67 \mathrm{cdef}$ & $22.33 \mathrm{cde}$ \\
\hline $5 \mathrm{t} /$ ha Poultry manure & Ibon 007 & $9.67 \mathrm{de}$ & $16.00 \mathrm{def}$ & $22.00 \mathrm{cde}$ \\
\hline 5 t/ha Poultry manure & Hausani & 9.00efg & $15.33 \mathrm{f}$ & $21.33 \mathrm{cde}$ \\
\hline $200 \mathrm{~kg} / \mathrm{ha}$ Organomineral fertilizer & F141 & $11.00 \mathrm{bcd}$ & $16.67 \mathrm{cdef}$ & $23.67 \mathrm{bcd}$ \\
\hline $200 \mathrm{~kg} / \mathrm{ha}$ Organomineral fertilizer & Ibon 007 & $8.67 \mathrm{efg}$ & 17.67abcd & $24.33 b c$ \\
\hline $200 \mathrm{~kg} / \mathrm{ha}$ Organomineral fertilizer & Hausani & 9.33def & $17.00 \mathrm{cdef}$ & $24.67 b c$ \\
\hline Control & F141 & $7.33 \mathrm{~g}$ & $13.00 \mathrm{~g}$ & $19.67 \mathrm{ef}$ \\
\hline Control & Ibon 007 & $7.67 \mathrm{fg}$ & $11.00 \mathrm{~h}$ & $17.33 f$ \\
\hline Control & Hausani & $7.67 \mathrm{fg}$ & $12.33 \mathrm{gh}$ & $19.67 \mathrm{ef}$ \\
\hline
\end{tabular}

Means followed by the same letter in the same column are not significantly different from each other at $5 \%$ level of probability by Tukey test. 
Table 10 shows the effects of sunshine organic manure, poultry manure, NPK (20-10-10), and organomineral fertilizers on the proximate composition of sugarcane. The proximate composition of the sugarcane differs significantly across all the treatments. Plots treated with $200 \mathrm{~kg} / \mathrm{ha}$ organomineral fertilizer recorded the highest percentage of ash (1.06) and fibre (15.29) respectively; and plots treated with $250 \mathrm{~kg} / \mathrm{ha}$ organomineral fertilizer recorded the highest percentage of moisture content (44.98). The highest percentage of crude protein and fibre was recorded in plots treated with $5 \mathrm{t} / \mathrm{ha}$ poultry manure. Plots treated with 5 tons/ha organic fertilizer recorded the highest percentage of fat; while plots treated with $200 \mathrm{~kg} / \mathrm{ha}$ organomineral fertilizer has the highest percentage of carbohydrate. However, the control plots recorded the lowest proximate composition across the treatments.

Table 10. Effects of fertilizer types on proximate composition of sugarcane.

\begin{tabular}{|c|c|c|c|c|c|c|}
\hline \multirow{2}{*}{ Treatments } & \multicolumn{6}{|c|}{ Proximate composition (\%) } \\
\hline & Ash & Mc & Cp & Fat & Fibre & Cho \\
\hline $250 \mathrm{~kg} / \mathrm{ha}$ organomineral fertilizer & $0.83 b$ & $44.98 \mathrm{a}$ & $5.25 \mathrm{a}$ & $0.11 \mathrm{c}$ & $13.47 \mathrm{a}$ & $32.78 \mathrm{e}$ \\
\hline $200 \mathrm{~kg} / \mathrm{ha}$ NPK fertilizer & $1.01 \mathrm{a}$ & $43.94 b$ & $3.95 \mathrm{c}$ & $0.23 \mathrm{ab}$ & $8.67 b$ & $52.72 \mathrm{a}$ \\
\hline 5 t/ha Poultry manure & $1.00 \mathrm{a}$ & $30.79 \mathrm{e}$ & $5.33 \mathrm{a}$ & $0.16 b c$ & $15.29 \mathrm{a}$ & $47.31 \mathrm{c}$ \\
\hline
\end{tabular}

Means followed by the same letter in the same column are not significantly different from each other at $5 \%$ level of probability by Tukey test.

Table 11 shows the effects of sunshine organic manure, poultry manure, NPK (20-10-10), and organomineral fertilizers on the nutrient composition of sugarcane. The nutrient uptake differed significantly across all the treatments. Plots treated with $5 \mathrm{t} / \mathrm{ha}$ poultry manure the highest nitrogen (1.31), plots treated with $250 \mathrm{~kg} / \mathrm{ha}$ organomineral fertilizer had the highest percentage phosphorus and manganese content $(0.55$ and 0.05$)$ while Plots treated with $200 \mathrm{~kg} / \mathrm{ha}$ NPK fertilizer has the highest percentage of potassium and sodium and magnesium (1.59, 1.76 and 3.08).

Data presented in Table 12 shows the effects of organic, inorganic and organomineral fertilizers on yield of sugarcane. Yield differed significantly $(p<$ $0.05)$ across treatments with plots treated with
$250 \mathrm{~kg} / \mathrm{ha}$ organomineral fertilizer having the highest yield value $(28.22 \mathrm{~kg} / \mathrm{ha})$. The lowest yield $(11.24$ $\mathrm{kg} / \mathrm{ha}$ ) was recorded in the control. The effects of organic, inorganic and organomineral fertilizers on the yield of the sugarcane varieties are also shown in Table 12. No significant differences were observed in the yield across the varieties. However, cane yield was higher in the Hauasani variety compared with others. The interaction effects of organic, inorganic and organomineral fertilizers and varieties on sugarcane yield are presented in Table 13. Yield differed significantly $(p<0.05)$ across treatments with plots treated with $250 \mathrm{~kg} / \mathrm{ha}$ organomineral fertilizer + Hausani having the highest yield value $(30.00 \mathrm{~kg} / \mathrm{ha})$. The lowest yield $(8.97 \mathrm{~kg} / \mathrm{ha})$ was recorded in the Control + Ibon 007 plots.

Table 11. Effects of fertilizer types on the nutrient composition of sugar cane.

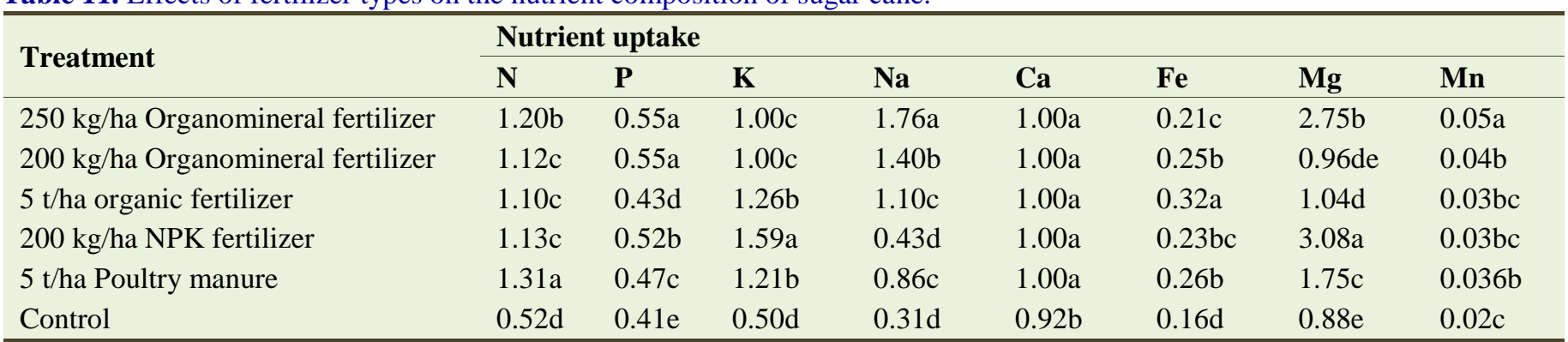

Means followed by the same letter in the same column are not significantly different from each other at $5 \%$ level of probability by Tukey test. 
Table 12. Effects of fertilizer types on cane yield $(\mathrm{kg})$ of sugarcane and sugarcane varieties.

\begin{tabular}{lc}
\hline Treatments & Mean \\
\hline $250 \mathrm{~kg} /$ ha organomineral fertilizer & $28.22 \mathrm{a}$ \\
$200 \mathrm{~kg} /$ ha organomineral fertilizer & $19.17 \mathrm{~b}$ \\
$200 \mathrm{~kg} /$ ha NPK fertilizer & $25.43 \mathrm{a}$ \\
5 t/ha organic fertilizer & $26.39 \mathrm{a}$ \\
5 t/ha poultry manure & $20.78 \mathrm{~b}$ \\
Control & $11.24 \mathrm{c}$ \\
Variety & $21.38 \mathrm{a}$ \\
F141 & $21.47 \mathrm{a}$ \\
Ibon007 & $22.77 \mathrm{a}$ \\
Hausani & \\
\hline
\end{tabular}

Means followed by the same letter in the same column are not significantlydifferent from each other at $5 \%$ level of probability by Tukey test.

Table 13. Interaction fertilizer types and varieties on the cane yield $(\mathrm{kg})$ of sugar cane.

\begin{tabular}{|c|c|c|}
\hline Fertilizer types & Variety & Mean \\
\hline $250 \mathrm{~kg} / \mathrm{ha}$ Organomineral fertilizer & F141 & $25.33 \mathrm{abc}$ \\
\hline $250 \mathrm{~kg} / \mathrm{ha}$ Organomineral fertilizer & Ibon 007 & $29.33 a$ \\
\hline $250 \mathrm{~kg} / \mathrm{ha}$ Organomineral fertilizer & Hausani & $30.00 \mathrm{a}$ \\
\hline $200 \mathrm{~kg} / \mathrm{ha}$ Organomineral fertilizer & F141 & $20.00 \mathrm{bcd}$ \\
\hline $200 \mathrm{~kg} / \mathrm{ha}$ Organomineral fertilizer & Ibon 007 & $19.67 \mathrm{bcd}$ \\
\hline $200 \mathrm{~kg} / \mathrm{ha}$ Organomineral fertilizer & Hausani & 22.67abcd \\
\hline $5 \mathrm{t} /$ ha organic fertilizer & F141 & $26.67 \mathrm{abc}$ \\
\hline 5 t/ha organic fertilizer & Ibon 007 & $27.33 \mathrm{ab}$ \\
\hline 5 t/ha organic fertilizer & Hausani & $25.17 \mathrm{abc}$ \\
\hline $200 \mathrm{~kg} / \mathrm{ha}$ NPK fertilizer & F141 & $26.83 \mathrm{ab}$ \\
\hline $200 \mathrm{~kg} / \mathrm{ha}$ NPK fertilizer & Ibon 007 & $24.00 \mathrm{abc}$ \\
\hline $200 \mathrm{~kg} / \mathrm{ha}$ NPK fertilizer & Hausani & $25.47 \mathrm{abc}$ \\
\hline $5 \mathrm{t} /$ ha Poultry manure & F141 & $19.67 \mathrm{bcd}$ \\
\hline $5 \mathrm{t} / \mathrm{ha}$ Poultry manure & Ibon 007 & $19.50 \mathrm{bcd}$ \\
\hline $5 \mathrm{t} / \mathrm{ha}$ Poultry manure & Hausani & $18.33 \mathrm{~cd}$ \\
\hline Control & F141 & $9.77 \mathrm{e}$ \\
\hline Control & Ibon 007 & $8.97 \mathrm{e}$ \\
\hline Control & Hausani & $15.00 \mathrm{de}$ \\
\hline
\end{tabular}

Means followed by the same letter in the same column are not significantly different from each other at $5 \%$ level of probability by Tukey test.

\section{Discussion}

The differences obtained in plant height among the sugarcane varieties may be attributable to genetic diversity, since they were grown under the same condition of fertilizer/manure application. However, the non significant differences in the plant height at seven months after planting might be due to the physiological maturity of the plants as plants tends to attained the same height at flowering. The higher plant height observed in the plots treated with $250 \mathrm{~kg} / \mathrm{ha}$ organomineral fertilizer might be due to higher nutrient contents in the $250 \mathrm{~kg} / \mathrm{ha}$ organomineral which was able to sustained the plant to maturity. The initial higher number of sugarcane leaves in plots applied with $200 \mathrm{~kg} / \mathrm{ha}$ NPK over the other treatments might be as a result of quick release of nutrients present in the NPK fertilizer which are responsible for leaves and root formation. This 
observation is in line with the findings of Moyinjesu (2007) who pointed out that organomineral and mineral fertilizers release their nutrients to the soil faster than organic manure.

Application of $250 \mathrm{~kg} / \mathrm{ha}$ organomineral fertilizer was slightly superior to the use of $200 \mathrm{~kg} / \mathrm{ha}$ NPK fertilizer on yield of sugarcane. This is in line with the results of Sridhar and Adeoye (2003) and Ogunlade et al. (2011) who reported that the use of organomineral fertilizer performed better on crop yield. The least performance of the plants in the control plots was a reflection of the soil nutrient deficit; while the significant response of yield attributes to N.P.K and organomineral fertilizers could be due to the effect of the nitrogen element on crop growth. Govinda et al. (1971) reported that the influence of $\mathrm{N}$ on shoot development (number of tillers) at early growth phase greatly influence cane development and yield. The higher yield observed in Ibon 007 varieties could be due to its increased number of tillers it produced during its growth. This was reported by Toomsan and Limpinuntana (2005) who suggested that higher cane yield could be attributed to the higher number of tillers and millable cane.

The lower values of crude protein found in plots treated with $200 \mathrm{~kg} / \mathrm{ha}$ NPK fertilizer and control could be due to the ease at which nutrients such as N, P, and K in NPK fertilizer was lost by leaching during the rainy season. The highest crude protein was recorded in poultry dropping at 5 tons/ha and this could be due to the fact that organic materials are more readily available in this type of manure since the materials have to be slowly decomposed and organic nutrients mineralized. This was observed by Bhullar et al. (2005) who reported that the slow decomposition of organic material release the nutrients over a long time during the crop growth period and also improves soil properties.

\section{Conclusion and recommendation}

The results of this study showed that the fertilizer examined had positive effects on sugarcane growth, yield and nutrition. However, organomineral fertilizer applied at $250 \mathrm{~kg} / \mathrm{ha}$ and Ibon 007 variety produced best results in terms of growth and yield. It can also be concluded that organomineral fertilizer can be a substitute for inorganic fertilizer in sugarcane production. This is due to the fact that the organomineral fertilizers are cheaper and boost soil fertility compared with non-N fortified organic fertilizers.
There is a need to encourage sugarcane farmers on the use of organomineral fertilizers to boost yield and quality. Planting of improved varieties of sugarcane should be encouraged by farmers in order to achieve optimum sugar yields. Additional research should also be carried out in various parts of Nigeria so as to give the findings a wider and more universal acceptance.

\section{Conflict of interest statement}

Author declares that he has no conflict of interest.

\section{References}

Alvaris, C. G., 2008. Growth of wheat as affected by $\mathrm{NaCl}$ and $\mathrm{Na}_{2} \mathrm{SO}_{4}$ salinity. 9th Int. Congress of Soil Sci. Abstracts (Soil Management under Stress Environment). Soil Science. Society of Pakistan. 2002. 47p.

Bhattacharya, P., Gehlot, D., 2003. Current status of organic forming at international and national level. Agrobios News Lett. 4, 7-9.

Bhullar, M.S., Kanboj, A., Sing, G.P., 2005. Influence of green manuring of intercropped short duration pulses on nitrogen management in spring sugarcane. Indian Sugar. 55(9), 71.

Busari, L. D., Ojehomon, V. E. T., Ndarubu, A. A., Gana, A. K., 1995. The challenge of chewing sugarcane production. NCRI Newslett. 1(1), 8.

Gana, A.K., 2008. Effect of organic and inorganic fertilizer on sugarcane production. Afr. J. Gen. Agric. 4(1), 55-59.

Girei, A. A., Giroh, D. J., 2012. Analysis of the factors affecting sugarcane (Saccharum officinarum) production under the out growers scheme in Numan local Government area Adamawa State, Nigeria. J. Educ. Pract. 3, 8.

Govinda, T.A., Krishnamoorthy, V. S., Ekambaram, C., Ranganathan, V., 1971. Nitrogen requirements and methods of application to sugarcane in Nellikuppam Tract. Madras Agric. J. 59(3), 180-184.

Hussain, F., Sarwar, M. A., Chattha, A. A., 2007. Screening of some sugarcane genotypes for gene quality. J. Anim. Plant Sci. 17(3-4), 76-78.

Misari, S. N., 1997. Traditional method of processing "Mazarkwaila and Alewa" from sugarcane National Cereal Research Institute, Agricultural Information Documentation and Dissemination. pp.1-21.

Moyinjesu, E. I., 2007. Use of plant resources for improving soil fertility, pod nutrients, root growth and pod weight of okra. Bioresour. Technol. 98, 2057-2064.

Mumtaz, A. S., Dur-e-Nayab, M., Iqbal, J., Shinwari, Z. K., 2011. Probing genetic diversity to characterize red rot resistance in sugarcane. Pak. J. Bot. 43(5), 2513-2517.

National Sugar Development Council (NSDC), 2003, Information Brochure towards Self Sufficiency in Sugar, Abuja. pp.1-26.

Ogunlade, M. O., Adeyemi, E. A., Ogunleti, D. O., Ibiyomi, P. S., 2011. Effect of cocoa pod husk, urea fortified cocoa 
pod husk and NPK fertilizers on the growth and yield of Solanum macrocarpon. Int. J. Organic Agric. Res. Develop. 3, 1-8.

Onwueme, L. C., Sinha, T. D., 1993. CTA -Field Crop Production in Tropical Africa. CTA, Wageningen, Netherlands. pp.401-411.

Onwueme, L. C., Sinha, T.D., 1999. CTA-Field Crop Production in Tropical Africa. CTA, Wageningen, Netherlands. pp.401-411.

Palaniappan, S. P., Annadurai, K., 1999. Organic Farming Theory and Practice. Scientific Publishers, Jodhpur India. pp.53-73.

Singh, S.N., Singh, A.K., Singh, S.C., Sharma, M.L., Kumar,
R., 2011. Enhancing sugarcane (Saccharum spp. Hybrid) productivity by integrating organic, inorganic and biological sources of $\mathrm{N}$ in sub-tropical India. Indian $\mathrm{J}$. Sugar Technol. 26(1), 14-15.

Sivanesan, A., Waller, J.M., 1986. Sugarcane diseases. CMI Phytopathology Paper No. 29. CAB International, Wallingford, U.K.

Sridhar, M. K. C., Adeoye, G. O., 2003. Organomineral fertilizer from urban wastes. Niger. Field. 68, $91-111$.

Toomsan, B., Limpinuntana, V., 2005. Effect of phosphorus on physiological and agronomic parameters of sugarcane cultivars in Thailand. Proc. Int. Soil .Sci. Technol. 25, 126 -131 .

\section{How to cite this article:}

Aiyelari, O. P., 2016. Effects of organic and inorganic fertilizers on the growth and yield of selected varieties of sugarcane (Saccharum officinarum). Int. J. Curr. Res. Biosci. Plant Biol. 3(8), 1-11.

doi: http://dx.doi.org/10.20546/ijcrbp.2016.308.001 